\title{
The System Mechanism of Land Management in the Digital Economy
}

\author{
Kuchumov A.V.* Terentyev S.E. Belokopytov A.V. \\ Smolensk State Agricultural Academy, 2. Smolensk, Russia \\ "Corresponding author. Email: upr.sgsha@mail.ru
}

\begin{abstract}
The article defines the mechanism of systemic land management in the digital economy, which allows both agricultural organizations and rural territories to effectively develop. The key macroconditions and microfactors of rational use of land resources, including investment and innovation climate, state monitoring and land valuation, technical and technological condition of production and economic use of agricultural land, are identified. As part of the study, an econometric model of the effective cultivation of grain crops using organic and mineral fertilizers in the region was built. The trends in the use of land resources in modern conditions are determined, the main directions for improving the use of agricultural land are substantiated, taking into account the development of seed production, the use of fertilizers, and state support. The proposed measures will make it possible to increase crop production in agricultural organizations of the Smolensk region by $10-12 \%$, and increase profitability by $6-8 \%$.
\end{abstract}

Keywords: land resources, agricultural organizations, digital economy, production efficiency, soil fertility,

profitability

\section{INTRODUCTION}

Economic sanctions, the complexity of the geopolitical situation suggests the need to strengthen the protective functions of the state from external factors and negative phenomena [1, 3]. First of all, this concerns the food security of the country and the development of the priority sphere - the agro-industrial complex. The import substitution policy and the economic pressure of the West require an increase in the competitiveness of domestic agricultural products, which is inextricably linked to the rational and efficient use of land resources [7, 8, 11].

According to the estimates of the Ministry of Agriculture of Russia, up to 40 million hectares of agricultural land have been withdrawn from economic turnover, which is onethird of the arable land currently available. Over the past two decades, the proportion of acidic soils has increased from 35 to $45 \%$. If the level of profitability in livestock industries can reach $30-40 \%$, then in crop production does not exceed 15-20\%. Increasing the profitability and return of land resources requires strengthening the intensification and optimal use of existing agricultural land $[2,4,5]$.

In the context of the digital economy and the innovative development of the country, the further development of agricultural production and rural areas largely depends on the rational use of agricultural land and its quality. Branches crop production is one of the backbone elements of the functioning of agro-towns and rural settlements $[6,10,12]$.

\section{MATERIAL AND METHODS}

The efficient use of land in agriculture is influenced by a large number of factors. In our opinion, in the context of an integrated approach, a system of effective land management of agricultural organizations should be defined, which allows for the growth of production efficiency and environmental friendliness, and the development of rural territories (Fig. 1). 


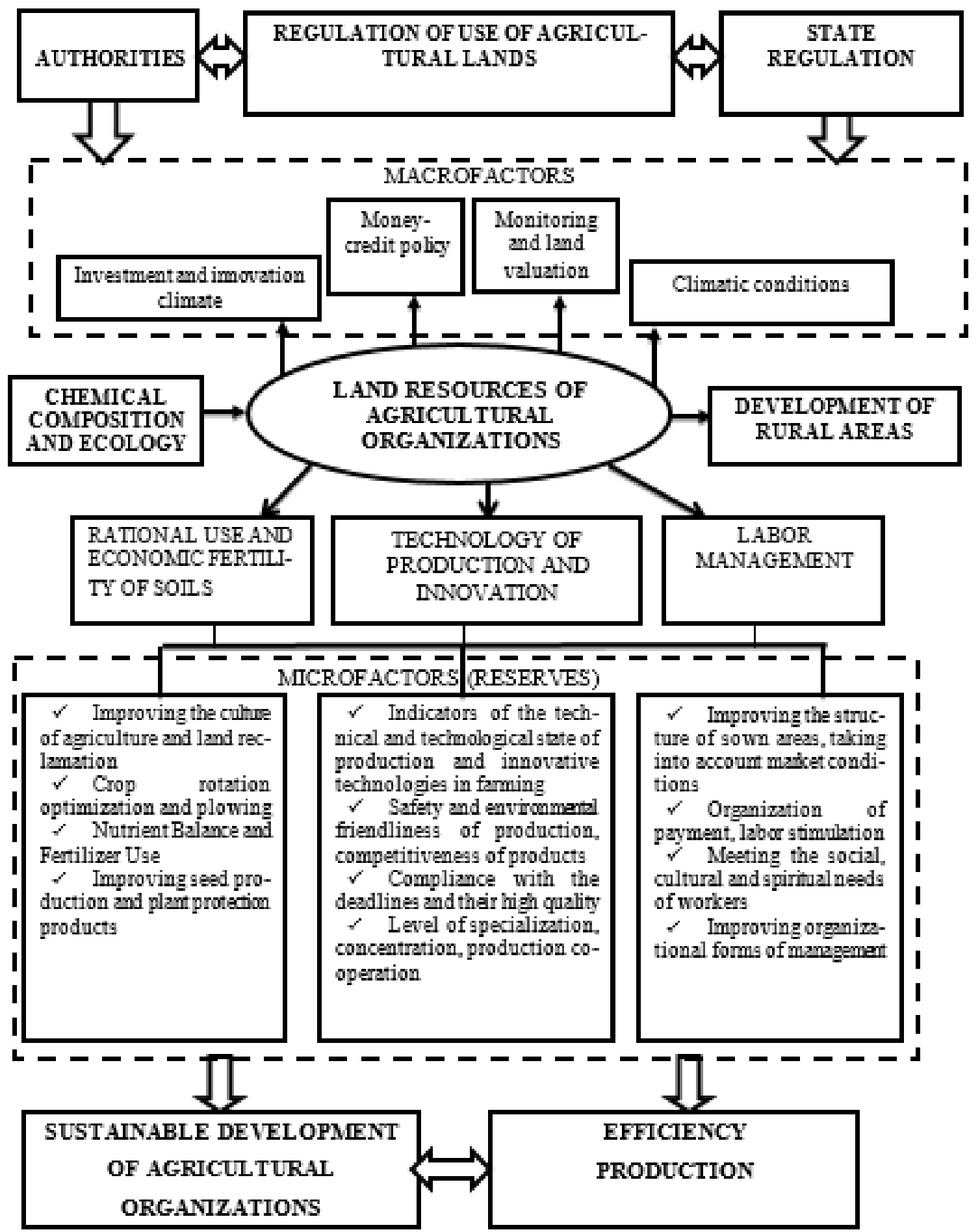

Figure 1 The system mechanism of effective land management of agricultural organizations in the digital economy 
Studies show that the mechanism of effective land management of agricultural organizations involves the consideration of micro- and macro-factors, determining the internal and external impact on the use of agricultural land. Only the complex influence of all conditions on the use of land resources entails an increase in the efficiency of agricultural production and the stability of the functioning of agricultural organizations.

In conditions of instability of the macro environment, the variability of the geopolitical situation, and low profitability of the agricultural sector, the state should provide significant support in regulating the use of agricultural land. It is unacceptable to concentrate large areas of agricultural land in the hands of large commercial companies that will try to withdraw them from economic circulation for their own use. One of the deterrence factors is the improvement of the legislative framework and the introduction of certain changes in regional and federal regulatory documents. Many regions of Russia already have positive experience in this area, in particular, Belgorod, Voronezh regions and other constituent entities of the Russian Federation [9, 14]. Other mechanisms for identifying unused agricultural land and their further involvement in circulation, which local authorities have within their powers, are land inventories, implementation of municipal land control and registration of unclaimed land shares into municipal ownership of rural settlements. So, in 2019, in the territory of the Smolensk region, $69 \%$ of the revealed unclaimed shares have already been legally registered in municipal ownership for their further involvement in economic turnover.

For the sake of systematic government measures, it is advisable to constantly monitor and evaluate agricultural land, to expand the range of monetary policy levers in the field of improving the use of agricultural land, protecting land and increasing their fertility. The current policy of the executive and legislative bodies should contribute to increasing the investment attractiveness of agricultural production, including in terms of the rational and efficient use of land resources by agricultural firms and agricultural holdings.

\section{RESULTS AND DISCUSSION}

In the production environment of the enterprise, the directions of efficient use and rational land management should be based on modern production technology, innovative technologies, rational organization of labor, improving the culture of agriculture and soil fertility. For the organization, given the complexity of influencing external development mechanisms, the priority remains to identify internal reserves for improving land management, developing conditions for their effective use.

The identification of significant reserves is possible taking into account the organizational and technical content of labor, the level of development of seed production and production specialization, finding ways to optimize crop rotation, land reclamation, the use of fertilizers and plant protection products. In conditions of low profitability of agricultural labour, an increase in production efficiency is possible with the use of rational organization and stimulation of labour, on the basis of improving organizational forms of management, optimizing the structure of sown areas taking into account market conditions, and increasing the competitiveness of products on an innovative basis.

According to state land accounting, the land fund of the Smolensk region as of 01.01.2019 is 4977.9 thousand ha. In the region, the structure of the land fund is dominated by agricultural land, which accounts for $44.6 \%$ (2219.4 thousand ha), followed by forest land - 39.8\% (1982.0 thousand ha), settlements - 5.8 (290.8 thousand ha) and other categories. The analysis shows that in 2018 the redistribution of areas of some land categories continued. To a greater extent, this affected agricultural lands, settlements, forest resources and stocks (Table 1).

Table 1 Distribution of the land fund of Smolensk region by categories at the end of the year, thousand hectares

\begin{tabular}{|c|c|c|c|c|}
\hline Name of land categories & 2005 & 2010 & 2018 & deviation, $+/-$ \\
\hline Agricultural land & 3230,1 & 2221.2 & 2219.4 & -1010.7 \\
\hline Settlements lands, including: & 269.5 & 280.7 & 290.8 & 21,3 \\
\hline Land for industry and other special purposes & 69.6 & 69.8 & 72.2 & 2.6 \\
\hline Lands of specially protected areas and objects & 114.6 & 114.6 & 114.6 & 0 \\
\hline Forest land & 895.6 & 1982,4 & 1982 & 1086,4 \\
\hline Lands of the water fund & 25.2 & 25,4 & 25,4 & 0.2 \\
\hline Land of stock & 373.3 & 283.8 & 273.5 & -99.8 \\
\hline Total land in the Smolensk region & 4977.9 & 4977.9 & 4977.9 & 0 \\
\hline
\end{tabular}

Studies show that over the past almost 15 years, more than 1 million hectares of agricultural land were withdrawn from economic circulation in the Smolensk region, which made up one-third of all the original land. The decrease was mainly due to the assignment of forest land plots previously used by agricultural organizations of this category to the category of forest fund lands (1086.4 thousand ha), as well as an increase in the land of settlements by 21.3 hectares, and transfer to land for industrial needs (2.6 ha). Most agricultural producers are not interested in expanding their agricultural areas, as own ones are not yet used inefficiently. These negative trends require increased government support and expansion of measures to stimulate the use of agricultural land and increase the involvement of neglected and uncultivated land in the turnover.

It is advisable to strengthen the incentives of agricultural producers for the rational use of land, including using the program-targeted method. Previously, there were federal 
and regional programs "Improving soil fertility for 20022005" then the federal target program "Preserving and restoring soil fertility in agricultural lands and agrolandscapes as Russia's national heritage for 2006 - 2010 and for the period until 2013", and today at the regional level there is no such program. An indirect factor in the target impact is only the federal target program "Development of Land Reclamation of Agricultural Land of Russia for 2014 - 2020", but its resources and influence are insufficient. Starting from 2020, the Ministry of Agriculture of the Russian Federation plans to compensate up to $30 \%$ of the costs associated with improving soil fertility under the federal program for the development of agriculture.

In the structure of agricultural land, the largest share is agricultural land - 1665.6 thousand hectares, including arable land - 1216.9 thousand hectares, hayfields, and pastures - 424.2 thousand hectares. For the period from 2005-2018, in agricultural organizations, the size of agricultural land decreased by $27.1 \%$ and amounted to $1,007.7$ thousand hectares. In addition, the area of arable land decreased by $28.2 \%$, and hayfields and pastures - by $21.8 \%$. Negative reduction trends are exacerbated by the incomplete use of legally assigned agricultural land by organizations. So, of the available land at the disposal of about $15 \%$ are not used, and $4 \%$ leased to other persons.

The utilization rate of arable land, the most important category of agricultural land, remains very low. The sown area of crops in agricultural organizations of the Smolensk region in 2018 was 211 thousand ha, which is about $80 \%$ of arable land.

The formation of a multi-layered economy is accompanied by a narrow specialization of agricultural production in the conditions of this or that region. Thus, in 2005-2018, the share of crop production decreased from $28.1 \%$ to $26.6 \%$ (4,056 million rubles) of the total gross agricultural output, livestock production in 2018 amounted to $73.4 \%$ (11191 million rubles). However, the structure of agricultural products varies significantly by producer category. Thus, in peasant farms in 2018, crop production accounted for $54.9 \%$ of production, while livestock production accounted for only $45.1 \%$. To a large extent, this is caused by factors of concentration and integration of production, as well as the cattle-breeding production area of the region.

There is an increase in the efficiency of land use in agricultural organizations in the Smolensk region, even taking into account inflationary processes. The analysis shows that the return on each hectare of land involved is increasing (Table 2). The value of gross agricultural products for the analyzed period increased by 11,996 million rubles, the result was 4.7 times more than in 2005 . At the same time, the share of crop production in the volume of production remains low and does not exceed $30 \%$.

Despite the positive trends of recent years, the effectiveness of land use in agriculture in the region remains low. The reason is that the applied management methods do not allow finding adequate solutions in radically changed economic conditions.

Positive trends can also be judged by the yield of agricultural crops, which increased during the study period. So, the yield of grain and leguminous crops amounted to $19.2 \mathrm{c}$ against $13.9 \mathrm{c}$ in 2005 , for potatoes $-212.7 \mathrm{c}$ against $98.1 \mathrm{c}$ in 2005 . However, in the ranking of the development of agricultural production among the subjects of the Central Federal District, the Smolensk region did not rise above tenth place.

Table 2 Efficiency of land use in agricultural organizations of the Smolensk region.

\begin{tabular}{|c|c|c|c|c|}
\hline & 2005 & 2010 & 2018 & 2018 to $2005, \%$ \\
\hline The total area of farmland, thousand ha & 1380.3 & 1053.2 & 1007.7 & -372.6 \\
\hline including arable land & 1050.9 & 790.3 & 748.3 & -302.6 \\
\hline Farmland per one subject, thousand ha & 4.1 & 2.6 & 2.5 & -1.6 \\
\hline The cost of agricultural products, million rubles & 3250.5 & 4831.1 & $15,246.7$ & 11996.2 \\
\hline \multicolumn{5}{|l|}{ The structure of agricultural products, $\%$ : } \\
\hline plant growing & 28.1 & 27.7 & 26.6 & -1.5 \\
\hline livestock & 71.9 & 72.3 & 73,4 & 1.5 \\
\hline \multicolumn{5}{|c|}{ Received per 1 ha of agricultural land, thousand rubles: } \\
\hline - gross output value & 2.4 & 4.6 & 15,1 & 12.7 \\
\hline - the cost of marketable products & 1.9 & 3.6 & 9,7 & 7.8 \\
\hline - profit margin & 0.01 & 0,26 & 0.97 & 0,96 \\
\hline \multicolumn{5}{|l|}{ Crop yield: } \\
\hline - grain and leguminous crops & 13.9 & 12.2 & 19.2 & 5,3 \\
\hline - potatoes & 98.1 & 97 & 212.7 & 114.6 \\
\hline The utilization of arable land, $\%$ & 98 & 99 & 81 & -17 \\
\hline
\end{tabular}

The effective use of agricultural land is largely due to an increase in the level of fertilizer application, both organic and mineral. So, per 1 hectare in $2018,47 \mathrm{~kg}$ of mineral (in terms of $100 \%$ of nutrients) and $1.6 \mathrm{~kg}$ of organic fertilizers were used, while the specific weight of the fertilized area was 48 and $6 \%$, respectively. Due to the high prices for mineral fertilizers, it is advisable to subsidize the costs of purchasing this resource to households. As part of the federal and regional agricultural development programs, up to $20 \%$ of the reimbursing cost of buying fertilizers is 
subsidized, but only to those agricultural producers who fulfil certain conditions of reproduction - the irreducible or increasing size of the sown area, the minimum sowing size for individual significant crops and other qualitative indicators of sustainable development of priority sectors. Econometric modelling provides an assessment of the stability of factor models in development $[13,15]$. Studies conducted on more than 40 agricultural enterprises in the region allowed us to build an econometric model of the efficiency of land use in the Smolensk region: $\mathrm{y}=16,77+2,59 * \mathrm{x}_{1}+0,22 * \mathrm{x}_{2} \quad \mathrm{R}^{2}=0,46$

where $\mathrm{y}$ is the yield of grain crops, $\mathrm{kg} / \mathrm{ha}$;

$\mathrm{X}_{1}$ - fertilizer application per 1 hectare of sowing, thousand rubles;

$\mathrm{X}_{2}$ - the application of organic fertilizers per 1 hectare of sowing, thousand rubles

Table 3 Indicators of fertilizer application in agricultural organizations of the Smolensk region

\begin{tabular}{|c|c|c|c|}
\hline Indicators & 2005 & 2010 & 2018 \\
\hline \multicolumn{4}{|l|}{ The level of fertilizer (in terms of $100 \%$ nutrients) } \\
\hline total, thousand tons & 4.7 & 4.6 & 11.4 \\
\hline per hectare of cultivated area, $\mathrm{kg}$ & 9 & 13 & 47 \\
\hline $\begin{array}{l}\text { The specific gravity of the area with mineral fertilizers in the entire } \\
\text { area, } \%\end{array}$ & 18 & 24 & 48 \\
\hline \multicolumn{4}{|l|}{ Organic fertilizer applied } \\
\hline total, thousand tons & 482.3 & 644 & 382.6 \\
\hline per hectare of cultivated area, $\mathrm{kg}$ & 1 & 2 & 1.6 \\
\hline The proportion of the area with organic fertilizers in the entire area, $\%$ & 3 & 5 & 6 \\
\hline
\end{tabular}

Studies show that up to $50 \%$ of changes in crop yields are associated with the intensification of production and the use of various fertilizers. Both the use of mineral and organic fertilizers can improve soil fertility, increase productivity and production efficiency in agricultural organizations in the region. So, an increase in the application of mineral fertilizers per 1 hectare of sowing grain crops by 1 thousand rubles leads to an average increase in productivity by 2.6 $\mathrm{c} / \mathrm{ha}$, and an additional introduction of organic matter into the soil in the amount of 1 thousand rubles. contributes to an increase in yield indicators by $0.22 \mathrm{~kg} / \mathrm{ha}$. The analysis of elasticity coefficients shows that the use of mineral fertilizers has the greatest effect on the yield of grain crops - a growth of $1 \%$ yields a $0.11 \%$ gain.

Improving the management of land resources under import substitution should be based on domestic seed production, it is necessary to use the own genetic potential of Russian varieties, which can easily compete with Western samples and are more adapted to the conditions of the NonChernozem zone of Russia, the zone of risky farming. The innovative potential of new varieties and hybrids ensures the effectiveness of modern agricultural technologies, increases the payback of technogenic factors of crop regulation due to its competitive advantages in productivity, quality and resistance to biotic and abiotic environmental factors. It is necessary to provide for higher cost compensation to agricultural producers within the framework of the state program, provided that it is the purchase of seed material of domestic production.

Table 4 Forecast of economic indicators and financial results of the Druzhba AGRICULTURAL PRODUCTION COOPERATIVE of the Smolensk region

\begin{tabular}{|c|c|c|c|}
\hline & 2018 & Forecast & Deviation, $+/-$ \\
\hline $\begin{array}{l}\text { The cost of agricultural products at current prices, thousand } \\
\text { rubles }\end{array}$ & 178053 & 196122 & 18069 \\
\hline $\begin{array}{l}\text { Cost of marketable products at selling prices, thousand } \\
\text { rubles }\end{array}$ & 146360 & 161023 & 14663 \\
\hline Amount of profit from sales, thousand rubles & 15913 & 21077 & 5164 \\
\hline The level of profitability of production, $\%$ & 12.2 & 18.5 & 6.3 \\
\hline
\end{tabular}

Currently, there are more than 10 seed-growing enterprises in the Smolensk region that make it possible to efficiently use elite domestic varieties as a factor in increasing the efficiency of land use. In this case, changes in the structure of sown areas, i.e. increase in the share of more productive crops in the total sown area. The calculations show that in the Druzhba AGRICULTURAL PRODUCTION COOPERATIVE due to the use of more optimal varieties of wheat, it is possible to increase the yield of agricultural crops and the efficient use of land resources. As a result of the proposed measures, an increase in the average yield of winter wheat by $4.2 \mathrm{c} / \mathrm{ha}$ is possible (the use of the Mera cultivar). Similarly, when using the Smolyanochka and Udacha varieties, the change in potato yield will be 62 and $44 \mathrm{~kg} / \mathrm{ha}$, respectively. 
[3] Volkov S.N., Shapovalov D.A., Klyushin P.V. Effektivnoye upravleniye zemel'nymi resursami osnova agrarnoy politiki Rossii. //Agroprodovol'stvennaya politika Rossii. 2017. № 11 (71). S. 2-7

[4] Demidov P.V., Ulez'ko A.V. Otsenka usloviy vosproizvodstva sel'skokhozyaystvennykh ugodiy. //Dal'nevostochnyy agrarnyy vestnik. 2018. № 2 (46). S. $176-184$

[5] Ivan'o YA.M., Chernigova D.R. Modelirovaniye izmenchivosti ploshchadi sel'skokhozyaystvennykh ugodiy $\mathrm{v}$ razlichnykh kategoriyakh predpriyatiy Irkutskoy oblasti. //Vestnik Altayskogo gosudarstvennogo agrarnogo universiteta. 2017. № 8 (154). S. 71-75

[6] Kosnikov S.N. Ekonomicheskaya effektivnost' ispol'zovaniya zemel'nykh resursov v sel'skokhozyaystvennykh organizatsiyakh Krasnodarskogo kraya. // Politematicheskiy setevoy elektronnyy nauchnyy zhurnal Kubanskogo gosudarstvennogo agrarnogo universiteta. 2015. № 107. S. 724-735

[7] Popov D.I. Otsenka sel'skokhozyaystvennykh ugodiy dlya tseley sovershenstvovaniya upravleniya zemel'nymi resursami v usloviyakh globalizatsii. //Nikonovskiye chteniya. 2011. № 16. S. 271-272

[8] Sidorenko O.V., Il'ina I.V. Effektivnoye ispol'zovaniye zemel'nykh resursov kak osnova importozameshcheniya v APK. //Zemledeliye. 2018. № 4. S. 3-5

[9] Smolentseva Ye.V. Ekonomicheskaya effektivnost' ispol'zovaniya zemel'nykh resursov v sel'skokhozyaystvennykh predpriyatiyakh Orichevskogo rayona Kirovskoy oblasti. //Modern Economy Success. 2017. № 4. S. 47-50

[10] Strekalovskaya M.I. Effektivnoye ispol'zovaniye zemel'nykh resursov v tselyakh ustoychivogo razvitiya severnogo regiona // Rossiyskoye predprinimatel'stvo. 2018. Tom 19. № 4. s. 991-1000.

[11] Dubovitski Alexander A., Karpunina Evgeniya K., Klimentova Elvira A., Cheremisina Natalia V. Ecological and Economic Foundations of Effective Land Use in Agriculture: The Implementation Prospects of Food Security. // EDUCATION EXCELLENCE AND INNOVATION MANAGEMENT THROUGH VISION 2020, pp.: 2687-2693, 2019 
[12] Qiu, Lefeng, Zhu Jinxia, Pan Yi, Wu Shaohua, Dang Yunxiao, $\mathrm{Xu}$, Baogen, Yang Hong The positive impacts of landscape fragmentation on the diversification of agricultural production in Zhejiang Province, China. //JOURNAL OF CLEANER PRODUCTION, Tom: 251, Article number: 119722, APR 2020.

[13] Terentyev, S.E., Lazko O.V., Belokopytov A.B. Organizational and economic aspects of the implementation of digital technologies in the innovative development of dairy cattle breeding //PROCEEDINGS OF THE 1ST INTERNATIONAL SCIENTIFIC CONFERENCE MODERN MANAGEMENT TRENDS AND THE DIGITAL ECONOMY: FROM REGIONAL DEVELOPMENT TO GLOBAL ECONOMIC GROWTH (MTDE 2019), Tom: 81 pp.: 46-51, 2019.

[14] Trofimov I. A. Trofimova L. S., Yakovleva E. P. Development of the Systematic Approach to Studying Agricultural Land and Agrolandscape Management. //BIOLOGY BULLETIN, Tom: 44, Release: 10, pp.: 1308-1315, DEC 2017.

[15] Voronkova O. Yu., Kovaleva I. V. Resource Potential and Production Efficiency High-Quality Organic Products in Russia. // QUALITY-ACCESS TO SUCCESS, Tom: 20, Release: 172, pp.: 114-117, OCT 2019. 